\title{
Dynamics of microbial plankton communities: experiments in Kaneohe Bay, Hawaii*
}

\author{
M. R. Landry ${ }^{1}$, L. W. Haas ${ }^{2}$ and V. L. Fagerness ${ }^{1}$ \\ ${ }^{1}$ School of Oceanography, University of Washington, Seattle, Washington 98195, USA \\ ${ }^{2}$ Virginia Institute of Marine Science, Gloucester Point, Virginia 23062, USA
}

\begin{abstract}
The dynamics of the microbial plankton community of Kaneohe Bay, Hawaii were investigated in September 1982 using in situ diffusion chambers and dilution manipulations. Total community carbon at the time of the experiments was estimated at $86 \mu \mathrm{g} \mathrm{Cl}^{-1}$ of which ChIorella sp. accounted for $47 \%$, autotrophic microflagellates $14 \%$, chroococcoid cyanobacteria $11 \%$, and heterotrophic microflagellates and bacteria each $9 \%$. Instantaneous growth rates ranged from 1.2 to $1.9 \mathrm{~d}^{-1}$ and 1.4 to $2.0 \mathrm{~d}^{-1}$, and mortality rates varied from 0.5 to $1.1 \mathrm{~d}^{-1}$ and 0.1 to $0.4 \mathrm{~d}^{-1}$ for heterotrophic bacteria and cyanobacteria, respectively, yielding net population growth rates of 1.0 to 1.3 and 1.5 to 2.7 doublings $\mathrm{d}^{-1}$ for the 2 populations. Chlorella sp., on the other hand, experienced only slight net growth $\left(0.1\right.$ to 0.3 doublings $\left.\mathrm{d}^{-1}\right)$ despite a growth coefficient of about $0.9 \mathrm{~d}^{-1}$. Phagotrophic microflagellates, presumed to be the dominant microbial grazers, consumed about 4.7 times their body carbon $\mathrm{d}^{-1}$ and grew at net population rates of 1.4 to 1.9 doublings $\mathrm{d}^{-1}$. However, microflagellates were food limited and did not control bacterial populations. From these data it appears that recent arguments for rapid material cycling within microbial communities of oligotrophic oceans may be overstated.
\end{abstract}

\section{INTRODUCTION}

The attention given marine microbes over the past decade has undeniably altered our perception of biomass structure, trophic relationships, and relevant processes in planktonic communities. Heterotrophic bacteria have emerged as a highly dynamic component of planktonic systems and an important consideration in material and energy cycling (Pomeroy, 1974; Azam and Hodson, 1977; Sieburth et al., 1978). Chroococcoid cyanobacteria, only recently discovered in the plankton, are now recognized as a ubiquitous and frequently substantial fraction of producer biomass (Johnson and Sieburth, 1979). Ciliated and flagellated protozooplankters have assumed new roles as trophic intermediates allowing efficient transfer of matter and energy from smaller producers to larger zooplankton (Beers and Stewart, 1967; Haas and Webb, 1979; Heinbokel and Beers, 1979). Phagotrophic microflagellates, moreover, are implicated in the control of bacterial populations (Fenchel, 1982a, b).

\footnotetext{
- Contribution No. 1352 from the School of Oceanography, University of Washington, Seattle, Washington 98195, USA, and the Virginia Institute of Marine Science, Gloucester Point, Virginia 23062, USA
}

Few investigators would argue that the classic macrofood chain of diatoms, copepods and fish adequately describes planktonic trophic structure, particularly in oligotrophic oceans where small organisms predominate. However, there is little consensus on what the new micro-food chain paradigm will ultimately mean for our understanding of ocean processes (e.g. Sorokin, 1971; Banse, 1974; Sieburth, 1977). Although much has been speculated from biomass and potential rate considerations, little is really known about the growth and dynamics of microbial plankton communities under natural conditions.

In the present study, we report on preliminary investigations of microbial community dynamics conducted as part of the PRPOOS (Planktonic Rate Processes in Oligotrophic Ocean Systems) Program experiments in Kaneohe Bay, Hawaii, September, 1982. The techniques we employ allow population growth and mortality rates to be dissociated and, thus, distinguish between populations that grow slowly and those that appear to grow slowly but cycle rapidly (i.e. where high growth rates are balanced by mortality). In addition, they yield useful inferences regarding the feeding behavior and growth efficiency of dominant consumers in the microbial community. 


\section{METHODS}

The experimental approach in the present study was based on the dilution technique of Landry and Hassett (1982) with 2 major refinements. First, the experiments were conducted in situ in diffusion cages to maintain relatively natural concentrations of dissolved nutrients throughout the experiment. This contrasts with the shipboard experiments with excess nutrients in Landry and Hassett (1982). Second, abundance estimates were made for organisms enumerated in individual taxa, not simply as community chlorophyll a. Thus, the present results provide a more detailed account of growth and mortality rates of different populations within the microbial community.

To avoid detrimental effects of heavy metal and plasticizer contamination on growth of the plankton community, all of the containers and transfer apparatus used in the experiments were subjected to thorough cleaning before use following a modified version of the Fitzwater et al. (1982) protocol. The various items were first rinsed with distilled water, soaked overnight in $10 \% \mathrm{HCl}$, and rinsed several more times with distilled water. They were then soaked for 4 to $5 \mathrm{~h}$ in warm Micro laboratory detergent (International Products, Inc.) and rinsed and soaked overnight with glass distilled water. This treatment was followed by rinses with Milli- $Q$ water, $1 \mathrm{~d}$ of soaking in $0.25 \mathrm{~N}$ quartz-distilled $\mathrm{HNO}_{3}$, and repeated rinses with Milli-Q water. Each item was then sealed in a plastic bag and rinsed several times with seawater immediately before use.

Experiments were conducted on successive days in a small embayment on Coconut Island, Kaneohe Bay, Hawaii in September, 1982. Water was collected in 101

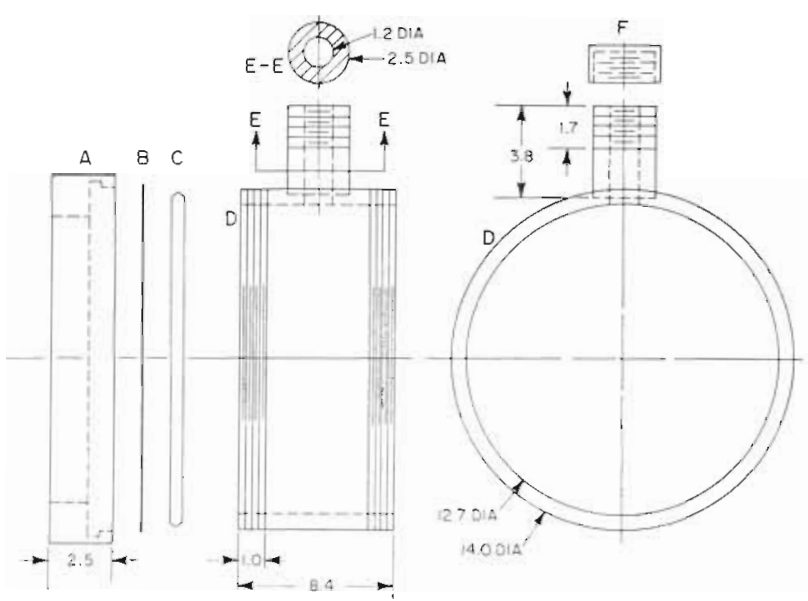

Fig. 1. Schematic diagram of an in situ diffusion chamber. Nuclepore membranes (B) and Teflon $O$ rings (C) are held in place by screw-on outer flanges (A). Main body (D) has capped opening $(E)$ for filling and emptying. Main body is constructed of Plexiglas round stock while outer flanges are machined from flat stock. All dimensions are in $\mathrm{cm}$ cubitainers by snorkel-divers and divided into 2 fractions - one maintained in its natural state, the other subjected to gentle gravity filtration to remove all or a specific component of the planktonic assemblage. For the first experiment, the water was passed through a $0.2 \mu \mathrm{m}$ Nuclepore filter (140 mm Teflon Millipore filtration apparatus) and then combined with unfiltered water to produce an initial fourfold dilution of the plankton community. For the second experiment, the filtered fraction was passed through a $1 \mu \mathrm{m}$ Nuclepore membrane, effectively eliminating organisms larger than bacteria; filtered and natural fractions were not recombined. For both experiments, 3 replicate samples of natural (unfiltered) seawater and three replicates of altered (dilution or $1 \mu \mathrm{m}$ filtered) seawater were prepared and transferred to 11 diffusion chambers fitted with $0.2 \mu \mathrm{m}$ Nuclepore membranes (Fig. 1). The chambers were individually tied by lengths of cord to rock anchors and bottle floats and suspended about $1 \mathrm{~m}$ off the bottom in a clearing between coral heads (about $5 \mathrm{~m}$ depth). After an incubation period of $24 \mathrm{~h}$ in situ, the chambers were recovered by divers.

Replicate samples from the initial water and final samples from each diffusion chamber were taken for pigment analyses and cell counts. Samples of $200 \mathrm{ml}$ for ciliate and large phytoplankton counts were preserved immediately with Lugol's iodine fixative. Samples for pigments $(400 \mathrm{ml})$ and bacteria/flagellate counts were processed in the laboratory a short distance away. Pigment samples were filtered on Whatman GF filters, ground in $90 \%$ acetone with a handdrill operated tissue grinder, and analyzed for chlorophyll a and phaeopigments by fluorescence (Lorenzen, 1966).

Subsamples of 5 to $25 \mathrm{ml}$ of water (depending on organism density) were prepared for epifluorescent microscopical enumeration of bacteria and flagellates according to the procedure of Haas (1982) which involves staining with the fluorochrome proflavin. Chroococcoid cyanobacteria were differentiated on the basis of their dense orange autofluorescence resulting from the pigment phycoerytherin. Autotrophic flagellates were distinguished from heterotrophic forms by the red autofluorescence of the chlorophyll molecule versus the green fluorochrome stain. The amount of proflavin used in staining was reduced from that used in eutrophic coastal environments $(1.6$ versus $6.6 \mu \mathrm{g} \mathrm{ml}^{-1}$ of sample, respectively) to minimize fluorochrome masking of chlorophyll autofluorescence. Flagellates were enumerated on each slide in 53 to 76 microscope fields (about 100 organisms per category). Because of their greater abundance, bacteria and cyanobacteria were counted on a proportionately smaller fraction of the slide; typically 100 to 600 cells of each category were counted per slide. Repli- 
cate counts on the same slide and on replicate slides from the same water sample revealed an average coefficient of variation of about $8 \%$ of the mean. All slides were enumerated within 1 wk of the end of the experiment. We observed, however, that all taxa could be maintained in excellent condition for as long as 4 mo if the slides were kept frozen at about $-15^{\circ} \mathrm{C}$.

Density estimates of the larger and rarer organisms in the experimental chambers were made from inverted microscope counts of 25 to $100 \mathrm{ml}$ aliquots from the Lugol's preserved samples. Centric and pennate diatoms, dinoflagellates, silicoflagellates, ciliates, and metazoans (copepod nauplii and copepodids) were differentiated and, where possible, were identified to genus.

Although the 2 experiments reported here represent slightly different approaches to estimating growth and mortality rates of individual microbial taxa in complex communities, both are based on comparing observed rates of population change in natural seawater versus an altered seawater condition (i.e. diluted or filtered). We assume that the relationship between the initial population density of an organism $\left(\mathrm{P}_{0}\right)$ and its final density $\left(P_{t}\right)$ at time ' $t$ ' can be represented by the exponential equation

$$
P_{t}=P_{o} e^{(k-g) t}
$$

where $\mathrm{k}$ and $\mathrm{g}=$ mean daily coefficients of population growth and mortality, respectively. The observed, i.e. measured, rate of change $\left(r_{n}\right)$ of the population under natural seawater conditions is, therefore,

$$
r_{n}=\frac{l}{t} \ln \left(\frac{P_{t}}{P_{o}}\right)=k-g
$$

We further assume, as in Landry and Hassett (1982), that the growth rates $(\mathrm{k})$ of autotrophic and bacterial populations in the diffusion chambers are unaffected by population density or by removal of predators but that mortality rate is proportional to predator density. Thus, in diluted seawater, the measured rate of population change $\left(\mathrm{r}_{\mathrm{d}}\right)$ is

$$
\mathrm{r}_{\mathrm{d}}=\mathrm{k}-\mathrm{xg}
$$

where the factor $\mathrm{x}=$ ratio of mean predator densities (assuming an exponential model of population increase from initial to final observed densities) in the diluted and natural conditions for the present experiment. In the $1 \mu \mathrm{m}$ filtered treatment, however, the measured rate of population change is assumed equal to population growth rate $(\mathrm{k})$ in the absence of predators. Both approaches, thus, ultimately reduce to two equations that can be solved for the two unknowns, $k$ and $\mathrm{g}$. It should be noted, however, that the approach using $1 \mu \mathrm{m}$ filtered water as the altered condition cannot distinguish growth and mortality rates of autotrophs larger than $1 \mu \mathrm{m}$ since they are removed with predators in the filtration step. In addition, neither approach can be used to estimate growth and mortality rates of consumers since prey levels, hence consumer growth rates, vary between experimental conditions.

\section{RESULTS}

Bacteria, small flagellates, and a Chlorella species dominated the plankton community of Kaneohe Bay at the time of our experiments (Table 1). Using a volumecarbon conversion factor of $1 \mu \mathrm{m}^{3}=10^{-7} \mu \mathrm{g} \mathrm{C}$ (e.g. Strickland, 1960), we estimate that total community carbon was about $86 \mu \mathrm{g} \mathrm{Cl} \mathrm{l}^{-1}$ of which Chlorella sp. accounted for $47 \%$, cyanobacteria $11 \%$, heterotrophic bacteria $9 \%$ and combined flagellate populations $23 \%$. By these calculations, autotrophic forms comprised about $75 \%$ of living organic carbon and had a mean carbon: chlorophyll a ratio of 135 . This compares well with a mean ratio of 115 determined for various locations around the Hawaiian Islands at about the same time (Redalje, pers. comm., using the chlorophyll a specific activity technique of Redalje and Laws, 1981).

Table 2 provides estimates of growth and mortality rates for the various components of the microbial plankton community of Kaneohe Bay. Both autotrophic and heterotrophic bacterial populations grew at about 3 doublings $\mathrm{d}^{-1}$. However, the net rate of population growth was greater for cyanobacteria since they apparently experienced less grazing mortality. Autotrophic microflagellates grew slowly during the experiments, and counts were quite variable between replicates; thus, they are not considered in detail here. Diatoms were also too variable to be considered although extremely high net rates of population growth (about 4 doublings $\mathrm{d}^{-1}$ ) were evident in both natural and diluted conditions. Growth and mortality rates were approximately balanced for the community biomass dominant Chlorella sp. Chlorophyll a concentration underwent apparent growth, mortality, and net changes intermediate between the lower rates observed for Chlorella sp. and autotrophic flagellates and the higher rates for cyanobacteria and diatoms. Net population growth of heterotrophic flagellates exceeded 1.5 doublings $\mathrm{d}^{-1}$ in the 2 experiments while ciliate populations changed little.

Although all component populations of the microbial community grew to some extent in the diffusion chambers, net growth rates were most rapid for diatoms, bacteria, and heterotrophic flagellates. Consequently, the community was substantially enriched in these populations after $1 \mathrm{~d}$ of incubation relative to initial conditions or to field conditions at the start of Experiment 2. For example, after $1 \mathrm{~d}$ in the chambers 
Table 1. Composition of the microbial plankton community of Kaneohe Bay, Hawaii, at the beginning of experiments conducted on successive days in September 1982. Carbon content estimates are based on volume

\begin{tabular}{|c|c|c|c|}
\hline \multirow{2}{*}{ Taxonomic category } & \multirow{2}{*}{$\begin{array}{l}\text { Est. carbon content } \\
\left(\mathrm{pg} \text { organism }{ }^{-1}\right)\end{array}$} & \multicolumn{2}{|c|}{ Abundance (number $\mathrm{ml}^{-1}$ ) } \\
\hline & & $\operatorname{Exp} \# 1$ & $\operatorname{Exp} \# 2$ \\
\hline Heterotrophic bacteria & 0.01 & 810,000 & 950,000 \\
\hline Chroococcoid cyanobacteria & 0.1 & 98,000 & 110,000 \\
\hline Chlorella sp. & 1.0 & 41,000 & 48,000 \\
\hline Autotrophic microflagellates & 6.0 & 2,000 & 940 \\
\hline Diatoms (Chaetoceros, Nitzschia) & 200. & 1.2 & nc \\
\hline Dinoflagellates & 700. & 2.4 & nc \\
\hline Silicoflagellates & - & 0.2 & nc \\
\hline Heterotrophic microflagellates & 6.0 & 970. & 890 \\
\hline Heterotrophic dinoflagellates & 20. & 20. & 10 \\
\hline Ciliated protozoans & 1,400 . & 1.4 & 1 \\
\hline Copepod nauplii & 100,000 & 0.05 & nc \\
\hline Total chlorophyll a $\left(\mu \mathrm{g} \mathrm{I}^{-1}\right)$ & & 0.48 & 0 \\
\hline Total estimated carbon $\left(\mu \mathrm{g} \mathrm{l}^{-\mathbf{1}}\right)$ & & 86. & \\
\hline
\end{tabular}

Table 2. Population growth $(\mathrm{k})$ and mortality $(\mathrm{g})$ estimates for various components of the microbial plankton community of Kaneohe Bay, Hawaii, from experiments conducted on successive days in September 1982. The instantaneous coefficient of population changes $\mathrm{r}=\mathrm{k}-\mathrm{g}$

\begin{tabular}{|lccc|}
\hline \multicolumn{1}{|c}{ Taxonomic category } & $\begin{array}{c}\text { Coefficient } \\
\left(\mathrm{d}^{-1}\right)\end{array}$ & & \\
\hline Heterotrophic bacteria & $\mathrm{k}$ & 1.93 & 1.17 \\
& $\mathrm{~g}$ & 1.09 & 0.51 \\
& $\mathrm{r}$ & 0.84 & 0.66 \\
Chroococcoid cyanobacteria & $\mathrm{k}$ & 1.98 & 1.42 \\
& $\mathrm{~g}$ & 0.14 & 0.39 \\
Chlorella sp. & $\mathrm{r}$ & 1.84 & 1.03 \\
& $\mathrm{k}$ & 0.87 & - \\
Autotrophic microflagellates & $\mathrm{g}$ & 0.67 & - \\
Diatoms & $\mathrm{r}$ & 0.20 & 0.10 \\
Autotrophic dinoflagellates & $\mathrm{r}$ & 0.14 & - \\
Heterotrophic microflagellates & $\mathrm{r}$ & 2.67 & - \\
Ciliated protozoans & $\mathrm{r}$ & 0.94 & - \\
Total chlorophyll a & $\mathrm{r}$ & 0.05 & - \\
& $\mathrm{k}$ & 1.58 & 1.60 \\
& $\mathrm{~g}$ & 0.35 & 0.47 \\
& $\mathrm{r}$ & 1.23 & 1.13 \\
\hline
\end{tabular}

cyanobacteria were 6 times more abundant than in the field. Heterotrophic flagellates and bacteria were 3 and 2 times more abundant, respectively. From our estimated carbon values, Chlorella sp. declined from 47 to $29 \%$ of community biomass during Experiment 1 and was replaced as biomass dominant by cyanobacteria which accounted for $36 \%$ of the estimated final carbon content of $171 \mu \mathrm{g} \mathrm{C1^{-1 }}$. As evidenced by the high net rates of accumulation of total chlorophyll and bacteria during the experiments, neither autotrophic nor bacterial populations were controlled by microbial consumers in the diffusion chambers.

\section{DISCUSSION}

Our experiments in Kaneohe Bay provide preliminary information on the dynamics of microbial plankton communities which suggest relatively rapid growth rates of bacterial and phytoplankton populations and lack of grazer control. In the discussion below, we first consider the limitations and critical assumptions of our experimental techniques and the evidence that these assumptions were met in the present study. Next, we demonstrate how data from such studies can be used to infer feeding relationships and growth efficiencies of dominant consumers. Finally, we discuss what our results imply about the nature of oligotrophic systems in which microbial food webs predominate.

Both the dilution and fractionation techniques described here yield growth and mortality data for microbial populations. On comparison, bacterial growth rate estimates were higher for the dilution approach in the present study. We attach no major significance to these discrepancies since the experiments were conducted on different days. However, we note that damage of bacterial cells in the fractionation step (i.e. passing the $1 \mu \mathrm{m}$ filter) could lead to lower estimates of bacterial growth in the second experiment. The dilution approach reduces the risk of working with damaged cells and also provides more information on larger size-fractions. Consequently, it is the preferable approach in studying microbial plankton dynamics.

The potential biases of the dilution technique have been described by Landry and Hassett (1982). Basically, the approach is contingent upon the assumptions that growth rates of the population of interest are identical in natural and diluted conditions and that 


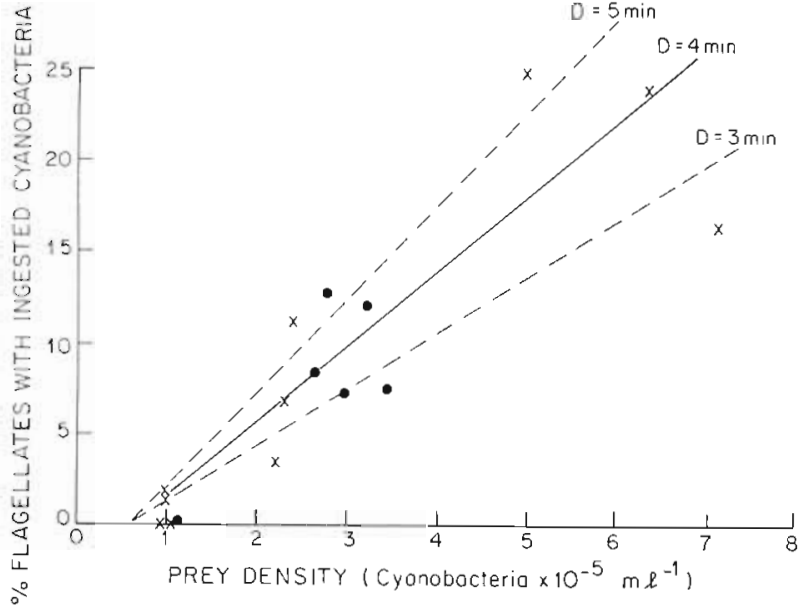

Fig. 2. Percentage of heterotrophic microflagellates containing ingested chroococcoid cyanobacteria as a function of cyanobacteria density in experiments conducted in Kaneohe Bay, Hawaii. Experiment $1=x$; Experiment $2=0$. Solid line corresponds to a random-encounter feeding model with a feeding threshold at 60,000 cyanobacteria $\mathrm{ml}^{-1}$, a mean clearance rate of $0.15 \mu \mathrm{l}$ flagellate $\mathrm{d}^{-1}$, and a mean digestion time of 4 min cyanobacterium ${ }^{-1}$. Broken lines: same model relationships with 3 and 5 min digestion times

consumer populations graze at similar clearance rates at the different prey densities. If population growth rate is substantially lower in the natural condition relative to the diluted condition, growth and mortality rates will be overestimated. On the other hand, if consumer grazing rates are saturated at the higher prey densities, growth and mortality rates will be underestimated. Two lines of evidence suggest that these assumptions were met in the present study. First, the growth rate of cyanobacteria in Kaneohe Bay was independently measured by track-autoradiography $1 \mathrm{wk}$ prior to our experiments. The resulting rate estimate was similar to our own $\left(\mathrm{k}=1.7 \mathrm{~d}^{-1}\right.$; Knoechel, pers. comm.). Second, our microscopical counts revealed that the fraction of heterotrophic flagellates with ingested cyanobacteria increased proportionately with cyanobacteria density (Fig. 2). This indicates that the flagellates were apparently not food satiated even at the unnaturally high food concentrations at the end of the experiments.

Growth and mortality estimates derived from dilution experiments can be used to infer maximum clearance and ingestion rates and minimum growth efficiencies of dominant consumer populations. From Landry (1981), per capita clearance rate (volume cleared of prey predator ${ }^{-1} \mathrm{~d}^{-1}$ ) can be calculated by dividing the prey's mortality coefficient by the mean density of predators (assuming an exponential rate of growth of the predator population). Ingestion rate (number of prey consumed predator ${ }^{-1} \mathrm{~d}^{-1}$ ) is then the mean prey density times the predator's clearance rate.
In the present experiments, ciliate and metazoan feeding account for no more than $10 \%$ of prey loss from energetic and clearance rate considerations. Hence, Table 3 ascribes all of the mortality in bacterial and Chlorella sp. populations to grazing by heterotrophic flagellates, which we assume feed phagotrophically.

Our estimate of clearance rates for the heterotrophic flagellates in Kaneohe Bay ranged from about 0.06 to $0.70 \mu \mathrm{d} \mathrm{d}^{-1}$ with no discernable pattern of increasing clearance efficiency with size of prey (Table 3 ). These estimates are in the mid range of values $(0.03$ to $1.9 \mu \mathrm{d} \mathrm{d}^{-1}$ ) reported by Fenchel (1982a) based on laboratory experiments with different species and sizes of flagellates. If we assume a mean clearance rate of $0.15 \mu \mathrm{d}^{-1}$ for flagellates feeding on cyanobacteria, the data in Fig. 2 are consistent with a randomencounter feeding model with a mean digestion time (i.e. time during which ingested prey are recognized) of 4 min cyanobacterium ${ }^{-1}$. Fig. 2 also implies a feeding threshold (e.g. Steele, 1974) at about $6 \times 10^{4}$ cyanobacteria $\mathrm{ml}^{-1}$, approximately $60 \%$ of natural prey densities. However, this may be the result of inadequate sample size at low densities. In retrospect, heterotrophic flagellates with recently ingested Chlorella sp. probably also occurred in our samples but may have been mistaken for autotrophic flagellates. An error of this kind would contribute to the variability of autotrophic flagellate counts and would lead to an underestimation of heterotrophic flagellate growth, hence, growth efficiency.

Ingestion rates of heterotrophic flagellates in Kaneohe Bay ranged from 400 to 900 heterotrophic bacteria, 18 to 41 cyanobacteria, and 19 Chlorella sp. $d^{-1}$ (Table 3 ). In terms of biomass, each flagellate

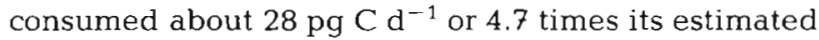
body carbon. Chlorella sp. accounted for 60 to $70 \%$ of the ingested prey by volume. Fenchel (1982a) reported maximum ingestion rates of 650 to 6,100 bacteria flagellate $\mathrm{d}^{-1} \mathrm{~d}^{-1}$ or 14.4 times body volume $\mathrm{d}^{-1}$ at food densities in excess of 2 to $5 \times 10^{7}$ bacteria $\mathrm{ml}^{-1}$. Given an estimated bacterial cell volume of $0.6 \mu \mathrm{m}^{3}$ (Fenchel, 1982 a), the above food concentrations are equivalent to 1,200 to $3,000 \mu \mathrm{g} \mathrm{Cl}^{-1}$. or about an order of magnitude greater than the total microbial community biomass of Kaneohe Bay. Fenchel (1982a) observed such high food densities to yield maximum growth rates of 3.6 to $6.0 \mathrm{~d}^{-1}$ (i.e. 5.4 to 9 doublings $\mathrm{d}^{-1}$ ) with a gross growth efficiency of about $30 \%$. The food-limited flagellates of Kaneohe Bay grew at much slower rates (.93 to $1.28 \mathrm{~d}^{-1}$; equivalent to 1.4 to 1.9 doublings $\mathrm{d}^{-1}$ ). Their estimated gross growth efficiency (ecological transfer efficiency $=$ observed increase in biomass/biomass ingested) was $22 \%$.

The 2 experiments in Kaneohe Bay, although not extensive, provide both interesting insights into the 
Table 3. Feeding rates of heterotrophic microflagellates estimated from experiments conducted on successive days in Kaneohe Bay, Hawaii, in September 1982. $F=$ clearance rate; $C=$ prey concentration; $I=$ ingestion rate expressed as cells flagellate ${ }^{-1}$ $\mathrm{d}^{-1} ; \mathrm{Ic}=$ ingestion rate expressed as carbon flagellate ${ }^{-1} \mathrm{~d}^{-1}$

\begin{tabular}{|c|c|c|c|c|}
\hline Prey type & $\begin{array}{c}F \\
\left(\mathrm{ml} \mathrm{flag}^{-1} \mathrm{~d}^{-1}\right)\end{array}$ & $\begin{array}{c}C \\
\text { (cells } \mathrm{ml}^{-1} \text { ) }\end{array}$ & $\begin{array}{c}\mathrm{I} \\
\text { (cells flag }{ }^{-1} \mathrm{~d}^{-1} \text { ) }\end{array}$ & $\begin{array}{c}\text { Ic } \\
\left(\mathrm{pgC} \mathrm{flag}{ }^{-1} \mathrm{~d}^{-1}\right)\end{array}$ \\
\hline Heterotrophic bacteria & $\begin{array}{ll}\operatorname{Exp} 1 & 0.705 \\
\operatorname{Exp} 2 & 0.229\end{array}$ & $\begin{array}{l}1.3 \times 10^{6} \\
1.4 \times 10^{6}\end{array}$ & $\begin{array}{l}899 \\
394\end{array}$ & $\begin{array}{l}9.0 \\
3.9\end{array}$ \\
\hline Chroococcoid cyanobacteria & $\begin{array}{ll}\operatorname{Exp} 1 & 0.063 \\
\operatorname{Exp} 2 & 0.215\end{array}$ & $\begin{array}{l}2.8 \times 10^{5} \\
1.9 \times 10^{5}\end{array}$ & $\begin{array}{l}18 \\
41\end{array}$ & $\begin{array}{l}1.8 \\
4.1\end{array}$ \\
\hline Chlorella sp. & Exp $1 \quad 0.421$ & $4.6 \times 10^{4}$ & 19 & 19.0 \\
\hline
\end{tabular}

dynamics of a particular planktonic assemblage and more general implications for understanding oligotrophic systems. It is evident, for example, that the control of phytoplankton and bacterial populations in Kaneohe Bay is not within the microbial community. Although the dominant small consumers, heterotrophic flagellates, are food-limited, producer populations can rapidly outgrow them in the short term. Thus, the maintenance of relatively stable phytoplankton and bacterial populations must be attributed to other processes, possibly advection but, more likely, grazing by other consumers not included in our experiments (e.g. larger pelagic zooplankton, demersal zooplankton, and corals). This would explain why diatoms are so successful in the cages that exclude large grazers.

Kaneohe Bay is considered eutrophic in comparison to the adjacent open ocean of Hawaii (Redalje and Laws, 1981). This is evident in the higher total biomass and the greater proportion of primary producers in the embayment. For example, we found that, relative to Kaneohe Bay, bacterial and heterotrophic flagellate populations in the open ocean off Kahe Point, Oahu, were lower by a factor of 25 to $30 \%$ while primary producers within the microbial plankton community (combined numbers of cyanobacteria, autotrophic flagellates, and Chlorella sp.) were reduced by two orders of magnitude and total chlorophyll a was about 1 order of magnitude lower (Table 4).

The new paradigm of oligotrophic oceans conceptualizes a highly dynamic microbial community in which production, grazing, and nutrient regeneration rates are rapid, balanced, and closely-coupled. The present study puts some constraints on this view. Given the degree of food-limitation for heterotrophic flagellates observed in the relatively enriched Kaneohe Bay, for instance, their counterparts in oligotrophic systems must be severely food-limited and slow-growing. In addition, bacterial populations (or primary producers, in general) in oligotrophic oceans may either grow rapidly or be controlled by flagellates but not both. If 700 flagellates $\mathrm{ml}^{-1}$ is a reasonable
Table 4. Comparison of compositions of the microbial plankton communities of Kaneohe Bay and Kahe Point, Hawaii, in September 1982

\begin{tabular}{|c|c|c|}
\hline \multirow[t]{2}{*}{ Taxonomic category } & \multicolumn{2}{|c|}{ Abundance (cells $\mathrm{ml}^{-1}$ ) } \\
\hline & Kaneohe Bay & Kahe Point \\
\hline Heterotrophic bacteria & 880,000 & 626,000 \\
\hline Chroococcoid cyanobacteria & 104,000 & 1,400 \\
\hline Autotrophic flagellates & 1,500 & 630 \\
\hline Chlorella sp. & 44,500 & 0 \\
\hline Heterotrophic flagellates & 930 & 700 \\
\hline Chlorophyll a & 0.52 & 0.06 \\
\hline
\end{tabular}

density for such systems and a mean clearance rate of $.7 \mu \mathrm{l}$ flagellate ${ }^{-1} \mathrm{~d}^{-1}$ (the maximum we measured) is appropriate, flagellate grazing can only balance bacterial production at bacterial growth rates less than 0.7 doublings $\mathrm{d}^{-1}$ (i.e. $\mathrm{k}=0.49 \mathrm{~d}^{-1}$ ).

In sum, the experiments reported here provide evidence for substantial, though not extraordinary, rates of population growth in a microbial plankton community. Observed growth rates of bacteria and flagellates are clearly suboptimal and, surprisingly, no greater than the growth of co-occurring diatoms. For the present, we suggest that arguments for rapid material cycling within microbial communities of oligotrophic oceans may be overstated. For the future, we look forward to applying the experimental techniques we develop here more directly to the question of plankton dynamics in oligotrophic oceans.

Acknowledgements. This study was conducted as part of the PRPOOS Program experiments at the Hawaiian Institute of Marine Biology, September, 1982. Funding was provided through National Science Foundation Grants OCE-8120842 to M. R. Landry and OCE-8110396 to L. W. Haas. We wish to acknowledge the exceptional efforts of R. W. Eppley, D. Osborne, D. Long, and E. Renger in coordinating the program and providing logistical support. In addition, we thank $D$. Long and E. Renger for help in placing and retrieving the in situ cages, J. Lehner-Fournier for providing Fig. 1, and M. Peacock for preparation of the manuscript. 


\section{LITERATURE CITED}

Azam, F., Hodson, R. E. (1977). Size distribution and activity of marine micro-heterotrophs. Limnol. Oceanogr. 22: 492-501

Banse, K. (1974). On the role of bacterial plankton in the tropical ocean. Mar. Biol. 24: 1-5

Beers, J R., Stewart, G. L. (1967). Micro-zooplankton in the euphotic zone at five locations across the California Current. J. Fish. Res. Bd Can. 24: 2053-2068

Fenchel, T. (1982a). Ecology of heterotrophic microflagellates. II. Bioenergetics and growth. Mar. Ecol. Prog. Ser. 8: $225-231$

Fenchel, T. (1982b). The bioenergetics of a heterotrophic microflagellate. Annls Inst. océanogr., Paris 58 (S): 55-60

Fitzwater, S. E., Knauer, G. A., Martin, J. H. (1982). Metal contamination and its effect on primary production measurements. Limnol. Oceanogr. 27: 544-551

Haas, L. W. (1982). Improved epifluorescence microscopy for observing planktonic microorganisms. Annls Inst. océanogr., Paris 58 (S) : 261-266

Haas, L. W., Webb, K. L. (1979). Nutritional mode of several non-pigmented microflagellates from the York River estuary, Virginia. J. exp. mar. Biol. Ecol. 39; 125-134

Heinbokel, J. F., Beers, J. R. (1979). Studies on the functional role of tintinnids in the Southern California Bight. III. Grazing impact of natural assemblages. Mar. Biol. 52: $23-32$

Johnson, P. W., Sieburth, J. McN. (1979). Chroococcoid cyanobacteria in the sea: a ubiquitous and diverse phototrophic biomass. Limnol. Oceanogr. 24: 928-308

Landry, M. R. (1981). Switching between herbivory and carnivory by a planktonic marine copepod, Calanus pacificus. Mar Biol. 65: 77-82

Landry, M. R., Hassett, R. P. (1982). Estimating the grazing impact of marine micro-zooplankton. Mar. Biol. 67: $283-288$

Lorenzen, C. J. (1966). A method for the continous measurement of in vivo chlorophyll concentration. Deep Sea Res. 13: $223-227$

Pomeroy, L. R. (1974). The ocean's food web, a changing paradigm. Bioscience 24: 499-504

Redalje, D. G., Laws, E. A. (1981). A new method for estimating phytoplankton growth rates and carbon biomass. Mar. Biol. 62: 73-79

Sieburth, J. McN. (1977). International Helgoland Symposium: Convener's report on the informal session on biomass and productivity of microorganisms in planktonic ecosystems. Helgoländer wiss. Meeresunters. 30:697-704

Sieburth, J. McN., Smetacek, V., Lenz, J. (1978). Pelagic ecosystem structure: heterotrophic compartments of the plankton and their relationship to plankton size fractions. Limnol. Oceanogr. 23: 1256-1263

Sorokin, Yu. 1. (1971). On the role of bacteria in the productivity of tropical oceanic waters. Int. Revue ges. Hydrobiol. 56: $1-48$

Steele, J. H. (1974). The structure of marine ecosystems. Harvard University Press, Cambridge

This paper was presented by Professor T. R. Parsons; it was accepted for printing on November 4, 1983 